\title{
The effects of propolis on sperm quality, reproductive organs and testicular antioxidant status of male rats treated with cyclosporine-A
}

\author{
B. Gul Baykalir ${ }^{1}$, P. Tatli Seven ${ }^{2,5}$, S. Gur ${ }^{3}$, I. Seven ${ }^{4}$ \\ ${ }^{1}$ University of Firat, Faculty of Veterinary Medicine, Department of Pharmacology and Toxicology, Elazig,Turkey. \\ ${ }^{2}$ University of Firat, Faculty of Veterinary Medicine, Department of Animal Nutrition and Nutritional Diseases, Elazig, Turkey. \\ ${ }^{3}$ University of Firat, Faculty of Veterinary Medicine, Department of Reproduction and Artificial Insemination, Elazig, Turkey. \\ ${ }^{4}$ University of Firat, Vocation School of Sivrice, Elazig, Turkey.
}

\begin{abstract}
This study was designed to determine the effects of propolis on the quality of sperm and reproductive organs in male rats treated with cyclosporine-A. In this study, 24 male Sprague-Dawley rats $(280-300 \mathrm{~g} \mathrm{BW})$ at 8-10 weeks of age were used. The rats were randomly divided into control and 3 treatment groups. Each rat was placed into a cage. During 21 days (experimental period), Group 1 served as control group; Group 2 (CsA) was given $15 \mathrm{mg} / \mathrm{kg}$ BW/day of CsA by subcutaneously; Group 3 (P) was given $100 \mathrm{mg} / \mathrm{kg} \mathrm{BW} /$ day of propolis by gavage; Group $4(\mathrm{CsA}+\mathrm{P})$ was given $15 \mathrm{mg} / \mathrm{kg} \mathrm{BW} /$ day of CsA subcutaneously and $100 \mathrm{mg} / \mathrm{kg} \mathrm{BW} /$ day of propolis by gavage. Administration of CsA to rats decreased sperm motility $(P<0.01)$ and sperm concentration $(P<0.01)$, and it increased total abnormal sperm rates $(\mathrm{P}<0.05)$ as compared with the control group. Significant improvements were observed in the sperm motility $(\mathrm{P}<0.01)$ and total abnormal sperm rates $(\mathrm{P}<0.05)$ in $\mathrm{Cs} \mathrm{A}+\mathrm{P}$ group. No significant differences were observed in the weights of right and left testes among all groups. The weight values of right and left epididymis were found similar to each other in CsA administrated groups. Seminal vesicle $(\mathrm{P}<0.01)$ and prostat glands weights $(\mathrm{P}<0.01)$ were significantly higher in $\mathrm{CsA}+\mathrm{P}$ group than CsA group. As a result, it was determined that oral supplementation of $100 \mathrm{mg} / \mathrm{kg}$ of propolis had amendatory effect on the quality of sperm and reproductive organs treated with CsA administered rats. CsA treatment caused a significant increase in MDA level $(\mathrm{P}<0.01)$ and significant decreases $(\mathrm{P}<0.01)$ in GSH level and CAT activity when compared with the control group. Ingestion of propolis by CsA-treated rats significantly decreased the MDA level and significantly increased the GSH level when compared with the CsA alone group $(\mathrm{P}<0.01)$.
\end{abstract}

Keywords: cyclosporine-A, propolis, rat, reproductive organs, sperm characteristics.

\section{Introduction}

Many environmental, physiological, and genetic factors have been implicated in the poor sperm functions and infertility (Vine, 1996; Auger et al., 2001; Kenkel et al., 2001; Sharlip et al., 2002).

Thus, it is very important to identify the factors/conditions which affect normal sperm functions.
Among various causes, oxidative stress has been attributed to affect the fertility status and physiology of spermatozoa (Agarwal et al., 2008). The term oxidative stress is generally applied when oxidants outnumber antioxidants (Du Plessis et al., 2008). The imbalance between the production of reactive oxygen species (ROS) and a biological systems ability to readily detoxify the reactive intermediates or easily repair the resulting damage is known as oxidative stress (Agarwal et al., 2003). The main destructive aspects of oxidative stress are the production of ROS, which include free radicals and peroxides (Bansal and Bilaspuri, 2011).

Cyclosporine-A (CsA) is an immunosuppressive drug that has considerably improved the survival of transplant patients in recent years (Xue et al., 1987; Sander and Victor, 1995; Rezzani et al., 2005). However, several side effects have been associated with CsA treatment, such as hypertension, nephrotoxicity and neurotoxicity (Tavares et al., 2003). The previous studies reported that CsA caused toxicities such as testicular (Sirinivas et al. 1998; Masuda et al., 2003) and spermatozoal toxicity (Seethalakshmi et al., 1990a, b; Iwasaki et al.,1996; Misro et al., 1999; Xu et al., 2003). All alterations in mitochondrial functions, covalent binding of CsA metabolites to proteins, elevated thromboxane synthesis, and lipid peroxidation have been implicated in the CsAmediated cell damage (Seethalakshmi et al., 1987). Whereas its precise toxic mechanisms remain to be investigated, lipid peroxidation ascribable to oxygen radicals produced in the kidney has been proposed to be one of the major mechanisms for CsA nephrotoxicity and cell injury, which are partly reversed by some antioxidants (Kumano et al., 1989).

Propolis contains approximately 300 constituents. Latterly, propolis has gained popularity in connection with oxidative stress (Tatli Seven et al., 2012) and used widely as a food additive to improve health and prevent diseases such as inflammation, heart disease, diabetes and even cancer (Burdock, 1998; Banskota et al., 2000). Propolis flavonoids are one of the most important compounds. Propolis compounds have been used for many biological and pharmacological activities including anticancer, antiinflammatory, antimicrobial and antioxidant (Sathiavelu et al., 2009; Tatli Seven et al., 2012). Propolis widely began to attract the attention of scientists. The results of many animal researches showed that propolis may relieve the negative effects of oxidative stress on the body's defense system (El-Khawaga et al., 2003; 
Mannaa et al., 2011; Tatli Seven et al., 2012). Propolis protects the reproductive system from toxicity, especially flavonoids and phenolic compounds are responsible for antioxidant activity and show protective effects against aluminium chloride which caused testicular dysfunction, deterioration in semen quality and testosterone levels (Yousef and Salama, 2009; Ogretmen et al., 2014). Previous studies have reported that propolis provides increments in testosterone level, body and reproductive organ weights, the percentage of motile sperm and normal-shaped sperm and seminal plasma enzymes, and it causes reductions in the levels of free radicals, lactate dehydrogenase in rabbits (Yousef et al., 2010). In addition, propolis decreases dead and abnormal sperm numbers and increases testosterone levels in rats (Meurer et al., 2009).

This study was planned to determine the effects of propolis on the quality of sperm and reproductive organs, and antioxidant status of testis tissue in rats treated with applied CsA.

\section{Material and Methods}

\section{Drugs}

CsA was obtained from Novartis, Istanbul, Turkey (Sandimmun ${ }^{\circledR}$ enj. sol. $50 \mathrm{mg} / \mathrm{ml}$ ) and propolis (dissolved in ethanol) was purchased from Ari Dunyasi Co., Istanbul, Turkey. The CsA was subcutaneously injected at the dose of $15 \mathrm{mg} / \mathrm{kg}$ and propolis was given by gavage daily at the dose of $100 \mathrm{mg} / \mathrm{kg}$ for 21 days. The CsA and propolis doses have been chosen, respectively, according to Kyung et al. (2003) and Rezzani et al. (2005).

\section{Animals, diets and treatments}

Twenty-four healthy adult male SpragueDawley rats (8-10 weeks old, 280-300 g BW) were used in this study. The animals were obtained from Firat University, Experimental Research Centre (Elazig, Turkey) and were housed in stainless steel cages under standard laboratory conditions $\left(24 \pm 3^{\circ} \mathrm{C}, \quad 40-60 \%\right.$ humidity, $12 \mathrm{~h}$ dark/light cycle). A standart commercial pellet diet (Elazig Food Company, Elazig, Turkey) containing $23 \%$ crude protein and $2650 \mathrm{kcal} / \mathrm{kg}$ metabolic energy, and fresh drinking water were provided ad libitum. The protocol for the use of animals was approved by the National Institutes of Health and Local Committee on Animal Research. This study was approved by the Animal Ethical Committee of Firat University (Elazig, Turkey). Rats were housed in individual cages.

The rats were randomly divided in four experimental groups of six rats each: control, CsA, propolis, and $\mathrm{CsA}+$ propolis groups. The rats in the control group were not given anything but commercial pellet diet and fresh water. The CsA group received CsA subcutaneous injection at $15 \mathrm{mg} / \mathrm{kg} / \mathrm{BW}$ per day for 21 days. The propolis group received propolis by gavage at $100 \mathrm{mg} / \mathrm{kg} \mathrm{BW}$ per day for 21 days. The CsA plus propolis group received CsA subcutaneous injection of CsA + propolis for 21 days. No rat died during the experimental period. After $24 \mathrm{~h}$ from last administration, rats were euthanized by cervical dislocation under the anesthesia with diethyl ether and reproductive tissues were removed for analysis. These samples were stored at $-20^{\circ} \mathrm{C}$ until further analysis.

\section{Extraction procedure of propolis}

Chromatographic analysis was carried out by Prevail $\mathrm{C}_{18}$ reversed-phase column (Grace Davison) (15 $\times 4.6 \mathrm{~mm}, 5 \mathrm{~mm}$, USA); the mobile phase was methanol/water/ acetonitrile (46/46/8, v/v/v) containing $1 \%$ acetic acid ( $\mathrm{Zu}$ et al., 2006). Quantification was done by the integration of the peak using external standard method. All chromatographic procedures were carried out at the temperature of $25^{\circ} \mathrm{C}$.

\section{Spectrophotometric assays}

\section{Analysis of total phenolics}

The amount of total phenolics in extracts was determined with the Folin-Ciocalteau reagent using the method of Velioglu et al. (1998). $0.75 \mathrm{ml} 0.1 \mathrm{~N}$ FolinCiocalteau reagent and $0.75 \mathrm{ml} \mathrm{Na}_{2} \mathrm{CO}_{3}(6 \%$, w/v) were added to $0.1 \mathrm{ml}$ of each sample. This procedure was replicated for three times. After $1.5 \mathrm{~h}$, the absorbance was measured at $725 \mathrm{~nm}$ using spectrophotometer. Results were expressed as $\mathrm{mg}$ gallic acid equivalent (GAE)/g fresh weight sample (Table 1).

Table 1. The total phenolic content, total flavonoid content and total antioxidant capacity values of propolis.

\begin{tabular}{lc}
\hline & Amounts in 1 g Propolis* \\
\hline Total phenolics & $139.1 \pm 1.8 \mathrm{mg} \mathrm{GAE}$ \\
Total flavonoids & $397.6 \pm 1.2 \mathrm{mg}$ QE \\
Total antioxidant capacity - CUPRAC & $494.5 \pm 1.3 \mathrm{mg}$ TEAC \\
\hline
\end{tabular}

*Values are given as mean \pm standard deviation of the values found for three parallel.

\section{Analysis of total flavonoids}

The total flavonoid content was determined using the colorimetric method reported by Kim et al. (2003). $1 \mathrm{ml}$ extract was mixed with $0.3 \mathrm{ml} 5 \% \mathrm{NaNO}_{2}$ at $\mathrm{t}=0 \mathrm{~min}$. Then $0.3 \mathrm{ml} 10 \% \mathrm{AlCl}_{3}$ was added at $\mathrm{t}=5$ min. After 6 min., $2 \mathrm{ml} 1 \mathrm{~N} \mathrm{NaOH}$ was added and the solution was mixed. The absorbance was measured against prepared water blank at $510 \mathrm{~nm}$. Total flavonoid content was expressed as $\mathrm{mg}$ quercetin equivalents
(QE)/g fresh weight sample (Table 1).

\section{Analysis of total antioxidant capacity - CUPRAC method}

The CUPRAC (cupric reducing antioxidant capacity) procedure was utilized using the method described by Apak et al. (2004). Firstly, $1 \mathrm{ml}$ of $0.01 \mathrm{M}$ copper (II) chloride $\left(\mathrm{CuCl}_{2}\right), 1 \mathrm{ml}$ of $0.0075 \mathrm{M}$ neocuproine $(\mathrm{Nc}), 1 \mathrm{ml}$ of ammonium acetate $\left(\mathrm{NH}_{4} \mathrm{Ac}\right)$ 
buffer ( $\mathrm{pH}$ 7.0) were mixed in a test tube. Subsequently, $0.1 \mathrm{ml}$ of sample extract or Trolox was added to this mixture. Finally, $1 \mathrm{ml}$ of MQ water was supplemented to make the final volume $4.1 \mathrm{ml}$. After $1 \mathrm{~h}$ reaction time, the absorbance was measured at $450 \mathrm{~nm}$. The results were expressed as mg Trolox Equivalent Antioxidant Capacity (TEAC)/g fresh weight sample (Table 1).

\section{Determination of phenolic profile by HPLC analysis}

Filtered extracts were analysed using a W600
Waters HPLC system coupled to a Waters 996 photodiode array (PDA) detector as described previously (Bino et al., 2005; Ahn et al., 2007). The compounds were separated using a C18 column (150 $\mathrm{x} 4.6 \mathrm{~mm}, 3 \mu$ ) and applying a gradient from 95 to $25 \%$ MQ and a $5-75 \%$ acetonitrile, both in $0.1 \%$ trifluoroacetic acid (TFA) (1 $\mathrm{ml} /$ minute flow rate) across a $50 \mathrm{~min}$ period. Phenolics of propolis were detected at 280, 312, and $360 \mathrm{~nm}$. For quantification, dose-response curves of available pure standards $(0-500 \mu \mathrm{g} / \mathrm{ml})$ were used as reference standard (Table 2).

Table 2. Phenolic substances and quantities defined in propolis.

\begin{tabular}{ll}
\hline Phenolics & $(\mathrm{mg} / \mathrm{g})^{*}$ \\
\hline Pinobanksin & $8.9 \pm 0.5$ \\
Pinostrobin & $5.5 \pm 0.3$ \\
Pinocembrin & $3.4 \pm 0.2$ \\
Chrysin & $2.7 \pm 0.1$ \\
Galangin & $2.2 \pm 0.2$ \\
Apigenin & $1.7 \pm 0.1$ \\
Kaempferol & $0.7 \pm 0.0$ \\
Luteolin & $0.6 \pm 0.0$ \\
\hline
\end{tabular}

*Values are given as mean \pm standard deviation of the values found for three parallel.

Determination of epididymal sperm concentration, motility and abnormal sperm rate

The sperm concentration was determined counting the spermatozoa in the right epididymis (Yokoi et al., 2003). The right epididymis was finely minced with anatomical scissors in $1 \mathrm{ml}$ of isotonic saline in a Petri dish. It was completely squashed by a tweezers for $2 \mathrm{~min}$., and then allowed to incubate at room temperature for $2 \mathrm{~min}$. to provide the migration of all spermatozoa from epididymal tissue to fluid. After incubation, the epididymal tissue-fluid mixture was filtered via strainer to separate the supernatant from tissue particles. The supernatant fluid containing all epididymal spermatozoa was drawn into the capillary tube up to 0.5 lines of the pipette designed for counting red blood cells. The solution containing $0.595 \mathrm{M}$ sodium bicarbonate, $1 \%$ formalin and $0.025 \%$ eosin was pulled into the bulb up to 101 lines of the pipette. The contents of the pipette were mixed by holding the ends of the pipette between the thumb and the index finger and shaking it vigorously in 100 back-and-forth $30 \mathrm{~cm}$ movements. The bulb of the pipette contains a small glass bead that makes thorough mixing possible. Sufficient solution was then blown from the pipette to ensure that the diluents containing no sperm were flushed from the capillary. This gave a dilution rate of $1: 200$ in this solution. Approximately $10 \mathrm{ml}$ of the diluted sperm suspension was transferred to both counting chambers of an Improved Neubauer (Deep 1/10 mm, LABART, Darmstadt, Germany) and allowed to stand for $5 \mathrm{~min}$. The sperm cells in both chambers were counted with the help of a light microscope at 200X magnification (Table 2).

The percentage of forward progressive sperm motility was evaluated using a light microscope with heated stage as described by Sonmez et al. (2007). For this process, a slide was placed on a light microscope with a heated stage warmed up to $37^{\circ} \mathrm{C}$, and then several droplets of Tris buffer solution $(0.3 \mathrm{M}$ Tris (hydroxymethyl) aminomethane, $0.027 \mathrm{M}$ glucose, 0.1 $\mathrm{M}$ citric acid) were dropped on the slide and a very small droplet of fluid obtained from left cauda epididymis with a pipette was added to the Tris buffer solution and mixed by a cover-slip. The percentage of forward progressive sperm motility was evaluated visually at $400 \mathrm{X}$ magnification. Motility was performed in three different fields in each sample. The mean of the three successive estimations was used as the final motility score.

To determine the percentage of morphologically abnormal spermatozoa, the slides stained with eosinenigrosin $(1.67 \%$ eosin, $10 \%$ nigrosin and $0.1 \mathrm{M}$ sodium citrate) were prepared. The slides were then viewed under a light microscope at $400 \mathrm{X}$ magnification. A total of 300 sperm cells was examined on each slide ( 2100 cells in each group), and the head, tail and total abnormality rates of spermatozoa were expressed as a percentage.

\section{Lipid peroxidation and antioxidant status}

\section{Malondialdehyde (MDA) determination}

The MDA level was measured as described by Candan and Tuzmen (2008). $1 \mathrm{~g}$ testis tissue sample was homogenized in $4 \mathrm{ml}$ of $20 \mathrm{mM}$ phosphate buffered saline $(\mathrm{pH}=7.4)$. Then the homogenate centrifuged at $15000 \mathrm{x} g$ for $15 \mathrm{~min}$. The supernatant was used for the analysis. Tissue lipoperoxides were hydrolyzed in diluted sulfuric acid $\left(\mathrm{H}_{2} \mathrm{SO}_{4}, 1 \%\right)$ and then these were boiled in phosphoric acid $\left(\mathrm{H}_{3} \mathrm{PO}_{4}\right)$. MDA is reacted with thiobarbituric acid (TBA) to form MDA-TBA-2 adduct. Tissue proteins are precipitated with methanol and 
removed from the reaction mixture by centrifugation. HPLC analysis was performed using Scimadzu LC20AT HPLC system. A mobile phase consisted of 40:60 (v/v) methanol- $\mathrm{KH}_{2} \mathrm{PO}_{4}$. The $\mathrm{C}_{18}$ column $(150 \mathrm{x}$ $4.6 \mathrm{~mm}, 5 \mu \mathrm{m}$, Fortis) was used with a flow rate of 0.6 $\mathrm{ml} /$ minute $\left(30^{\circ} \mathrm{C}\right)$, sample run was $10 \mathrm{~min}$, injection volume was $20 \mu \mathrm{l}$ and fluorescence detector wavelengths were set at $532 \mathrm{~nm}$ (excitation) and 553 $\mathrm{nm}$ (emission). Results were expressed $\mu \mathrm{g} / \mathrm{ml}$ homogenate.

\section{Reduced glutathione (GSH) level}

The GSH level was measured spectrophotometrically at $412 \mathrm{~nm}$ using the method of Ellman (1959). The protein content in the testis was measured using the method of Lowry et al. (1951) with bovine serum albumin as the standard. The GSH level was expressed as nmol/mg protein.

\section{Catalase (CAT) activity}

The testis tissue CAT activity was determined according to the method of Aebi (1984). The principle of the method is based on the determination of the rate constant $(k)$ for the $\mathrm{H}_{2} \mathrm{O}_{2}$ decomposition rate at $240 \mathrm{~nm}$. Results were expressed as k/g protein.

\section{Statistical analysis}

All values are presented as mean \pm standard deviation (SD). Differences were considered to be significant at $\mathrm{P}<0.05$. Statistical analysis was performed using the one-way ANOVA and post hoc Duncan's significance difference test by SPSS 21, IBM, 2012 program.

\section{Results}

\section{Sperm characteristics}

Epididymal sperm motility, sperm concentration, abnormal sperm rates and reproductive organ weights are presented in Table 3. Although a significant decrease $(\mathrm{P}<0.01)$ was found for sperm motility and concentration in the CsA group when compared with the control group, no difference was observed in sperm motility of the $\mathrm{CsA}+\mathrm{P}$ group as compared with the control group. Administration of propolis to CsA-treated rats was able to prevent the CsA-induced reduction in sperm motility but not in sperm concentration in comparison with the CsA alone group. A significant increase $(\mathrm{P}<0.05)$ was observed in abnormal sperm rate in CsA group alone when compared with the control group but propolis administration to CsA-treated rats significantly decreased this rate. No statistically significant differences were found in the values of right and left testis weights between the groups. CsA treatment significantly reduced the weights of epididimydes $(\mathrm{P}<0.05)$ and all accessory glands $(\mathrm{P}<0.01)$ when compared to the control group but propolis administration to CsA-treated rats increased these weights. However, the increments that were found only in the weights of right cauda epididymis and accessory glands after propolis administration had a statistical significance $(\mathrm{P}<0.01)$.

CsA treatment caused a significant increase $(\mathrm{P}<0.01)$ in MDA level and significant decreases $(\mathrm{P}<0.01)$ in GSH level and CAT activity when compared with the control group. Ingestion of propolis by CsA-treated rats significantly decreased the MDA level and significantly increased the GSH level when compared with the CsA alone group ( $\mathrm{P}<0.01$; Table 4).

able 3. The effects of propolis on the quality of sperm and reproductive organs of experimental groups (g).

\begin{tabular}{|c|c|c|c|c|c|}
\hline & Control & CsA & Propolis & CsA+Propolis & $\mathrm{P}$ \\
\hline Motility (\%) & $70.00 \pm 4.47^{\mathrm{a}}$ & $45.83 \pm 4.55^{\mathrm{b}}$ & $68.33 \pm 4.77^{\mathrm{a}}$ & $61.67 \pm 5.43^{\mathrm{a}}$ & $* *$ \\
\hline Concentration (milion/cauda) & $370.00 \pm 18.44^{\mathrm{a}}$ & $238.33 \pm 26.88^{\mathrm{c}}$ & $323.33 \pm 28.13^{\mathrm{ab}}$ & $260.00 \pm 20.33^{b c}$ & $* *$ \\
\hline Abnormal spermatozoid rate $(\%)$ & $2.33 \pm 0.33^{\mathrm{a}}$ & $4.50 \pm 0.44^{\mathrm{b}}$ & $2.66 \pm 0.42^{\mathrm{a}}$ & $3.16 \pm 0.30^{\mathrm{a}}$ & $*$ \\
\hline Right Testis Weight (g) & $1.38 \pm 0.06$ & $1.13 \pm 0.15$ & $1.42 \pm 0.08$ & $1.22 \pm 0.07$ & NS \\
\hline Left Testis Weight (g) & $1.40 \pm 0.06$ & $1.24 \pm 0.12$ & $1.38 \pm 0.06$ & $1.20 \pm 0.16$ & NS \\
\hline Right Epididymis (g) & $0.54 \pm 0.02^{\mathrm{a}}$ & $0.39 \pm 0.07^{\mathrm{b}}$ & $0.56 \pm 0.03^{\mathrm{a}}$ & $0.47 \pm 0.03^{\mathrm{ab}}$ & $*$ \\
\hline Left Epididymis(g) & $0.60 \pm 0.03^{\mathrm{a}}$ & $0.43 \pm 0.05^{\mathrm{c}}$ & $0.56 \pm 0.03^{\mathrm{ab}}$ & $0.45 \pm 0.05^{\mathrm{bc}}$ & * \\
\hline Seminal vesicles $(\mathrm{g})$ & $1.16 \pm 0.03^{\mathrm{a}}$ & $0.51 \pm 0.09^{c}$ & $1.16 \pm 0.08^{\mathrm{a}}$ & $0.85 \pm 0.09^{\mathrm{b}}$ & $* *$ \\
\hline Prostate (g) & $0.61 \pm 0.07^{\mathrm{a}}$ & $0.33 \pm 0.05^{\mathrm{b}}$ & $0.56 \pm 0.02^{\mathrm{a}}$ & $0.49 \pm 0.05^{\mathrm{a}}$ & $* *$ \\
\hline Right Caudo (g) & $0.22 \pm 0.01^{\mathrm{a}}$ & $0.13 \pm 0.03^{\mathrm{b}}$ & $0.21 \pm 0.01^{\mathrm{a}}$ & $0.16 \pm 0.01^{\mathrm{b}}$ & $* *$ \\
\hline
\end{tabular}

${ }_{\mathrm{a}, \mathrm{b}, \mathrm{c}}$ Mean values with different superscripts within a row differ significantly; NS: Non significant; $* \mathrm{P}<0.05 ; * * \mathrm{P}<0.01$.

Table 4. Effects of propolis on MDA ( $\mu \mathrm{g} / \mathrm{ml}$ homogenate), CAT (k/g protein) and GSH (nmol/mg protein) activities in testis tissue of experimental groups.

\begin{tabular}{rlcrrrr}
\hline & & Control & CsA & Propolis & \multicolumn{1}{c}{ CsA+Propolis } & P \\
\hline \multirow{3}{*}{ Testis } & MDA & $1.14 \pm 0.004^{\mathrm{c}}$ & $5.74 \pm 0.55^{\mathrm{a}}$ & $1.14 \pm 0.001^{\mathrm{c}}$ & $3.04 \pm 0.03^{\mathrm{b}}$ & $* *$ \\
& CAT & $0.63 \pm 1.39^{\mathrm{a}}$ & $0.34 \pm 0.10^{\mathrm{c}}$ & $0.60 \pm 0.07^{\mathrm{a}}$ & $0.47 \pm 0.08^{\mathrm{b}}$ & $* *$ \\
& GSH & $64.30 \pm 14.21^{\mathrm{a}}$ & $47.50 \pm 5.6^{\mathrm{b}}$ & $46.63 \pm 7.29^{\mathrm{b}}$ & $52.57 \pm 9.21^{\mathrm{b}}$ & $* *$ \\
\hline
\end{tabular}

${ }^{\mathrm{a}, \mathrm{b}, \mathrm{c}}$ Mean values with different superscripts within a row differ significantly; $* * \mathrm{P}<0.01$.

\section{Discussion}

CsA treatment is probably responsible for the pathogenesis of testicular and spermatozoal toxicity associated with the oxidative stress. Although CsAinduced nephrotoxicity and hepatotoxicity are related with oxidative stress, there is no evidence concerning the relationship between cellular/biochemical 
mechanisms of gonadal damage and oxidative stress (Turk et al., 2007). ROS are normally synthesized in several essential metabolic processes for living cells including the spermatozoa. Spermatozoa are especially sensitive to peroxidative damage because of high concentration of polyunsaturated fatty acids, which are involved in arranging of sperm maturation, spermatogenesis, capacitation, acrosome reaction and eventually in membrane fusion, and low antioxidant capacity. The lipid matrix of sperm membrane is destroyed by the peroxidation of lipids, and it is associated with rapid loss of intracellular ATP leading to axonemal damage, reduced sperm viability and increased mid-piece morphological defects, and besides it fully prevents spermatogenesis in extreme status (Sanocka and Kurpisz, 2004). In this study, it was indicated that CsA treatment significantly decreased sperm concentration and motility, and increased abnormal sperm rate in comparison with the control group. These results are in agreement with previous studies at which was indicated that CsA caused spermatozoal damage (Seethalakshmi et al., 1987; Seethalakshmi et al., 1990a, b; Iwasaki et al., 1996; Misro et al., 1999; Xu et al., 2003; Turk et al., 2007, 2010). Especially, sperm motility is an important functional measurement to predict sperm fertilizing capacity. Any negative impact on motility would seriously affect fertilizing ability (ElMazoudy et al., 2011). Moreover, treatment with propolis extract prevented CsA-induced reduction in sperm motility and, it increased sperm motility of rats in the propolis group ( $\mathrm{P}<0.01$; Table 3 ). Consistent with the present results, Capucho et al. (2012) and Rizk et al. (2014) reported that propolis extract can increase the sperm count of rats. According to these findings, propolis may be have an adjuvant therapy. Testicular tissue that induced by CSA was protected from oxidation by propolis administration. Rizk et al. (2014) reported that administration of propolis extract to normal rats increased sperm count by $31.20 \%$ as compared with the control group. Sperm motility may be affected by altered enzymatic activities of oxidative phosphorolytic process. Oxidative phosphorolytic process is required for ATP production, a source of energy for the forward movement of spermatozoa (ElMazoudy et al., 2011).

It has been reported that the CsA administration causes a decrease in the reproductive organ weights of non-transplanted male rats (Turk et al., 2007, 2010). CsA caused significant negative effects on reproductive organ weights except for testis weights in the present study. The secretory activity of accessory glands is dependent on testosterone produced by the Leyding cell. It was reported that CsA administration leads to decrease in the level of testosterone (Sikka et al., 1988a, b). The decline in reproductive organ weights except for testis weights observed in the study may be explained by the fact that the secretion of this organ likely decreased because testosterone levels were reduced by CsA. Consistent with the findings of a study done by ElMazoudy et al. (2011) propolis administration increased $(\mathrm{P}<0.01)$ seminal vesicles and prostate weights and alleviated the negative effects of
CsA in the present study.

CsA treatment caused a significant increase in testicular tissue MDA level in comparison with the control, and co-administrations of propolis with CsA caused significant decrease in MDA levels, and significant increase in CAT, when compared with the CsA group. This finding is in agreement with the findings of the studies done by Turk et al. $(2007,2010)$. The increment in MDA levels are probably because of the extreme generation of ROS by blocking the permeability transition pore, providing an increase in $\mathrm{Ca}^{2+}$ concentration, and distruption of mitochondrial electron transport chain (Fournier et al., 1987; Nicolli et al., 1996). When ROS began to be kept under control, testes exhibit a defensive mechanism using different antioxidant enzymes. The primary detoxifying systems for peroxides are CAT and GSH. CAT is an antioxidant enzyme, which overthrows $\mathrm{H}_{2} \mathrm{O}_{2}$ that can form a highly reactive $\mathrm{OH}$ in the presence of iron as a catalyst (Sikka, 1996). After entering into redox cycle of gluthation, $\mathrm{H}_{2} \mathrm{O}_{2}$ and lipid peroxides were coverted to nontoxic products by GSH and GSH-Px (Nicolli et al., 1996; Sharma and Agarwal,1996; Sikka, 1996; Sanocka and Kurpisz, 2004). Decreasing activity of antioxidant systems is due to the toxic effect of CsA that causes an increase in lipid peroxidation and oxidative stress and subsequently testicular and spermatozoal toxicity. Phenolic compounds derived from pomegranate, vitamins $\mathrm{C}, \mathrm{E}$, melatonin, lycopene have been used as antioxidant agents to prevent different organs from various lipid-peroxidation-induced damages (Turk et al., 2008). Propolis treatment partially ameliorated the CsA-induced imbalance in oxidant-antioxidant system of testes (Table 4). Especially, propolis supplementation to rats treated with CsA significantly decreased the MDA level $(\mathrm{P}<0.01)$, increased CAT activity $(\mathrm{P}<$ 0.01 ) but had no effect on GSH activity in comparison with the CsA group.

The first mechanism of this effect of propolis may involve the scavenging of free radicals that causes lipid peroxidation. The second mechanism can be its ability to prevent the xanthine oxidase activity, which is known to cause generation of free radicals. The reason for increase in CAT activity and decrease in MDA level of $\mathrm{CsA}+\mathrm{P}$ group in the present study may be explained by potent free radical scavenging activity of flavonoid content of propolis (Attia et al., 2012). Flavonoids and other phenolic compounds found in propolis seem to be capable of scavenging free radicals avoiding lipids and other substances such as vitamin $\mathrm{C}$ to be oxidized or destroyed during oxidative damage (Seven et al., 2014). Otherwise, flavonoids inhibit lipid peroxidation, platelet aggregation, capillary permeability and fragility, and the activity of enzyme systems including cyclooxygenase and lipoxygenase (Seven et al., 2014). These results clearly demonstrate the important role of oxidative stress and its relation to testicular toxicity and also point out the protective potential of propolis against CsA. At least in part, the protection afforded by propolis is mediated through inhibiting testicular lipid peroxidation and increasing CAT contents in that tissue (Seven et al., 2014). 
In conclusion, propolis appeared to ameliorate the toxicity on sperm quality and reproductive organs of CsA by scavenging the free radicals and increasing the antioxidant activities. Therefore, propolis administration may be a good option to diminish the negative effects of $\mathrm{CsA}$ on male reproduction in transplanted patients.

\section{Acknowledgment}

We would like to thank Prof.Dr. Dilek BOYACIOGLU and Assoc.Prof.Dr. Esra CAPANOGLU GUVEN for compositional analysis of propolis.

\section{References}

Aebi H. 1984. Catalase in vitro methods in enzymology. In: Willam BJ (Ed). Methods in Enzymology. New York, NY: Academic Press. pp. 121126.

Agarwal A, Saleh RA, Bedaiwy MA. 2003. Role of reactive oxygen species in the pathophysiology of human reproduction. Fertil Steril, 79:829-843.

Agarwal A, Makker K, Sharma R. 2008. Clinical relevance of oxidative stress in male factor infertility: an update. Am J Reprod Immunol, 59:2-11.

Ahn MR, Kumazawa S, Usui Y, Nakamura J, Matsuka M, Zhu F, Nakayama T. 2007. Antioxidant activity and constituents of propolis collected in various areas of China. Food Chem, 101:1383-1392.

Apak R, Guclu K, Ozyurek M, Karademir SE. 2004. Novel total antioxidantcapacity index for dietary polyphenols and vitamins $\mathrm{C}$ and $\mathrm{E}$, using their cupric ion reducing capability in the presence of neocuproine: CUPRAC method. J Agric Food Chem, 52:7970-7981.

Attia AA, EIMazoudy RH, El-Shenawy NS. 2012. Antioxidant role of propolis extract against oxidative damage of testicular tissue induced by insecticide chlorpyrifos in rats. Pestic Biochem Physiol, 103:87-93. Auger J, Eustache F, Andersen AG, Irvine DS, Jorgensen N, Skakkebaek NE, Suominen J, Toppari J, Vierula M, Jouannet P. 2001. Sperm morphological defects related to environment, lifestyle and medical history of 1001 male partners of pregnant women from four European cities. Hum Reprod, 16:2710-2717.

Bansal AK, Bilaspuri GS. 2011. Impacts of oxidative stress and antioxidants on semen functions. Vet Med Int, 2011:1-7.

Banskota AH, Tezuka Y, Adnyana IK, Midorikawa K, Matsushige K,Message D, Huertas AA, Kadota S 2000. Cytotoxic, hepatoprotective and free radical scavenging effects of propolis from Brazil, Peru, the Netherlands and China. J Ethnopharmacol, 72:239-246.

Bino RJ, de Vos CHR, Lieberman M, Hall RD, Bovy A, Jonker HH, Tikunov Y, Lommen A, Moco S, Levin I. 2005. The light-hyperresponsive high pigment$2 \mathrm{dg}$ mutation of tomato: alterations in the fruit metabolome. New Phytol, 166:427-438.

Burdock GA. 1998. Review of the biological properties and toxicity of bee propolis (Propolis). Food Chem Toxicol, 36:347-363.

Candan N, Tuzmen N. 2008. Very rapid quantification of malondialdehyde (MDA) in rat brain exposed to lead, aluminium and phenolic antioxidants by highperformance liquid chromatography-fluorescence detection. Neurotoxicology, 29:708-713.

Capucho C, Sette R, Predes F, Monteiro JC, Pigoso AA, Barbieri R, Heidi Dolder MA, Severi Aguiar GDC. 2012. Green Brazilian propolis effects on sperm count and epididymis morphology and oxidative stress. Food Chem Toxicol, 50:3956-3962.

Du Plessis SS, Makker K, Desai NR, Agarwal A. 2008. Impact of oxidative stress on IVF. Expert Rev Obstet Gynecol, 3:539-554.

El-Khawaga OA, Salem TA, Elshal MF. 2003. Protective role of Egyptian propolis against tumor in mice. Clin Chim Acta, 338:11-16.

Ellman GL. 1959. Tissue sulfhydryl groups. Arch Biochem Biophys, 82:70-77.

EIMazoudy RH, Attia AA, El-Shenawy NS. 2011. Protective role of propolis against reproductive toxicity of chlorpyrifos in male rats. Pestic Biochem Physiol, 101:175-181

Fournier N, Ducet G, Crevat A. 1987. Action of cyclosporine on mitochondrial calcium fluxes. $J$ Bioenerg Biomembr, 19:297-303.

Iwasaki M, Fuse H, Katayama T. 1996. [The effects of cyclosporin azathioprine and mizoribine on male reproduction in rats]. Nippon Hinyokika Gakkai Zasshi, 87:42-49.

Kenkel S, Rolf C, Nieschlag E. 2001. Occupational risks for male fertility: an analysis of patients attending a tertiary referral centre. Int $J$ Androl, 24:318-326.

Kim D, Jeong SW, Lee CY. 2003. Antioxidant capacity of phenolicphytochemicals from various cultivars of plums. Food Chem, 81:321-326.

Kumano K, Yashida K, Iwamura M, End T, Sakai T, Nakamura K, Kuwoo T. 1989. The role of reactive oxygen species in cyclosporin A induced nephrotoxicity in rats. Transplant Proc, 21:941-942.

Kyung WS, Mijung P, Yeon JS, Sung-Jin K, Kwang RY. 2003. The protective effects of propolis on hepatic injury and its mechanism. Phytother Res, 17:250-253.

Lowry OH, Rosebrough NJ, Farr AL, Randall RJ. 1951. Protein measurement with the folin phenol reagent. J Biol Chem, 193:265-275.

Mannaa F, El-Shamy KA, El-Shaikh KA, ElKassaby M. 2011. Efficacy of fishliver oil and propolis as neuroprotective agents in pilocarpine epileptic rats treated with valproate. Pathophysiology, 18:287-294.

Masuda H, Fujihira S, Ueno $H$, Kagawa $M$, Katsuoka Y, Mori H. 2003. Ultrastructural study on cytotoxic effects of cyclosporine A in spermiogenesis in rats. Med Electron Microsc, 36:183-191.

Meurer F, Costa MMD, Barros DAD, Oliveira STL, Paixao PS. 2009. Brown propolis extract in feed as a growth promoter of Nile tilapia (Oreochromis niloticus, Linnaeus 1758) fingerlings. Aquacult Res, 40:603-608.

Misro MM, Chaki SP, Srinivas M, Chaube SK. 1999. Effect of cyclosporine on human sperm motility in vitro. Arch Androl, 43:215-220.

Nicolli A, Basso E, Petronilli V, Wenger RM, Bernard P. 1996. Interactions of cyclophilin with the mitochondrial inner membrane and regulation of the permeability transition pore, cyclosporine A-sensitive 
channel. J Biol Chem, 271:2185-2192.

Ogretmen F, Inanan BE, Ozturk M. 2014. Protective effects of propolis on cryopreservation of common carp (Cyprinus carpio) sperm. Cryobiology, 68:107-112.

Rezzani R, Giugno L, Buffoli B, Bonomini F, Bianchi R. 2005. The protective effect of caffeic acid phenethyl ester against cyclosporine A-induced cardiotoxicity in rats. Toxicology, 212:155-164.

Rizk SM, Zaki HF, Mina MAM. 2014. Propolis attenuates doxorubicin-1nduced testicular toxicity in rats. Food Chem Toxicol, 67:176-186.

Sander M, Victor RG. 1995. Hypertension after cardiac transplantation: Pathophysiology and management. Curr Opin Nephrol Hy, 4(5):443-451.

Sanocka D, Kurpisz M. 2004. Reactive oxygen species and sperm cells. Reprod Biol Endocrinol, 2:1-7.

Sathiavelu J, Senapathy GJ, Devaraj R, Namasivayam N. 2009. Hepato-protective effect of chrysin on prooxidant-antioxidant status during ethanolinduced toxicity in female albino rats. $J$ Pharm Pharmacol, 61:809-817.

Seethalakshmi L, Menon M, Malhotra RK, Diamond DA. 1987. Effect of cyclosporine A on male reproduction in rats. $J$ Urol, 138:991-995.

Seethalakshmi L, Flores C, Diamond DA, Menon M 1990a. Reversal of the toxic effects of cyclosporine on male reproduction and kidney function of rats by simultaneous administration of hCG + FSH. J Urol, 144:1489-1492.

Seethalakshmi L, Flores C, Khauli RB, Diamond DA, Menon M. 1990b. Evaluation of the effect of experimental cyclosporine toxicity on male reproduction and renal function. Reversal by concomitant human chorionic fonadotropin administration. Transplantation, 49:17-19.

Seven I, Gul Baykalir B, Tatli Seven P, Dagoglu G. 2014. The ameliorative effects of propolis against cyclosporine a induced hepatotoxicity and nephrotoxicity in rats. Kafkas Univ Vet Fak Derg, 20:641-648.

Sharlip ID, Jarow JP, Belker AM, Lipshultz LI, Sigman M, Thomas AJ, Schlegel PN, Howards SS, Nehra A, Damewood MD, Overstreet JW, Sadovsky R. 2002. Best practice policies for male infertility. Fertil Steril, 77:873-882.

Sharma RK, Agarwal A. 1996. Role of reactive oxygen species in male infertility. Urology, 48:835-850.

Sikka SC, Bhasin S, Coy DC, Koyle MA, Swerdloff RS, Rajfer J. 1988a. Effects of cyclosporine on the hypothalamic-pituitary-gonadal axis in the male rat: mechanism of action. Endocrinology, 123:1069-1074.

Sikka SC, Coy DC, Lemmi CA, Rajfer J. 1988b Effect of cyclosporine on steroidogenesis in rat Leydig cells. Transplantation, 46:886-890.

Sikka SC. 1996. Oxidative stress and role of antioxidants in normal and abnormal sperm function. Front Biosci, 1:78-86.

Sirinivas M, Agarwala S, Datta Gupta S, Das SN, Jha P, Misro MM, Mitra DK. 1998. Effect of cyclosporine on fertility in male rats. Pediatr Surg Int, 13:388-391.

Sonmez M, Yuce A, Turk G. 2007. The protective effects of melatonin and vitamin $\mathrm{E}$ on antioxidant enzyme activities activities and epididymal sperm characteristics of homocysteine treated male rats. Reprod Toxicol, 23:226-231.

Tatli Seven P, Yilmaz S, Seven I, Tuna Kelestemur

G. 2012. Effects of propolis in animals exposed oxidative stress. In: Lushchak VI (Ed.). Oxidative Stress-Environmental Induction and Dietary Antioxidants. Rijeka, Croatia: InTech. pp. 267-288.

Tavares P, Fontes Ribeiro CA, Teixeira F. 2003. Cyclosporin effect onnoradrenaline release from the sympathetic nervous endings of rat aorta. Pharmacol Res, 47:27-33.

Turk G, Atessahin A, Sonmez M, Yuce A, Ceribasi AO. 2007. Lycopene protects against cyclosporine Ainduced testicular toxicity in rats. Theriogenology, 67:778-785.

Turk G, Sonmez M, Aydin M, Yuce A, Gur S, Yuksel M, Aksu EH, Aksoy H. 2008. Effects of pomegranate juice consumption on sperm quality, spermatogenic cell density, antioxidant activity and testosterone level in male rats. Clin Nutr, 27:289-296.

Turk G, Sonmez M, Ceribasi AO, Yüce A, Atessahin A. 2010. Attenuation of cyclosporine A-induced testicular and spermatozoal damages associated with oxidative stress by ellagic acid. Int Immunopharmacol, 10:177-182.

Velioglu YS, Mazza G, Gao L, Oomah BD. 1998. Antioxidant activity andtotal phenolics in selected fruits, vegetables, and grain products. J Agric Food Chem, 46:4113-4117.

Vine MF. 1996. Smoking and male reproduction: a review. Int J Androl, 19:323-337.

Xu LG, Xu HM, Zhang JR, Song QZ, Qi XP, Wang XH. 2003. [Effects of different dosages of cyclosporine A on the semen parameters of renal transplant patients]. Zhonghua Nan Ke Xue, 9:679-683.

Xue H, Buroski RD, McCarron DA, Bennett WM. 1987. Production of contraction in isolated rat aorta by cyclosporin. Transplantation, 43:715-718.

Yokoi K, Uthus EO, Nielsen FH. 2003. Nickel deficiency diminishes sperm quantity and movement in rats. Biol Trace Elem Res, 93,141-153.

Yousef MI, Kamel KI, Hassan MS, El-Morsy A. 2010. Protective role of propolis against reproductive toxicity of triphenyltin in male rabbits. Food Chem Toxicol, 48:1846-1852.

Yousef MI, Salama AF. 2009. Propolis protection from reproductive toxicity caused by aluminium chloride in male rats. Food Chem Toxicol, 47,1168-1175.

Zu Y, Li C, Fu Y, Zhao C. 2006. Simultaneous determination of catechin, rutin, quercetin kaempferol and isorhamnetin in the extract of sea buckthorn (Hippophae rhamnoides L.) leaves by RP-HPLC with DAD. J Pharma Biomed Anal, 41:714-719. 